\title{
Enquete: Betragtninger om danskhed og jantelov
}

Tænd for radioens Program 1. Grib en tilfældig søndagsavis og slå op på kultursiderne. Man skal ikke vente mange minutter eller lede længe. Danskheden blive vendt og drejet, holdt op og betragtet fra forskellige vinkler. I disse i øvrigt vidt forskellige beskrivelser er der enkelte begreber, som går igen, og som derfor - alene baseret på den slidstyrke og frekvens, de optræder med - må antages at have en eller anden forbindelse i virkeligheden. Det er ord som „hygge“, ,,ironi“ - og ,,jantelov“.

Hyggen er danskerne som regel stolte af. Vi er flinke folk, rare at være i stue med. Hygge er godt for betalingsbalancen. Den kan tiltrække turister, og når nu det danske sommervejr gør den danske naturoplevelse upålidelig, så er det heldigt, at vi har indendørskultur, vi kan sælge: „Die Hyggelige Dänen“. Ironien, den sofistikerede humoristiske sans, er der heller ikke de store problemer med, selvom denne form for metakommunikation frembyder nogen vanskeligheder for utrænede udlændinge. Janteloven, derimod, har danskerne selv et tvetydigt forhold til. De fleste accepterer uden videre, at janteloven er så dansk som rødgrød med fløde. Men de samme danskere ville blive smækfornærmede, hvis nogen skulle finde på at sige, at deres konkrete handlinger var udtryk for jantementalitet. Lad os tage janteloven lidt nærmere i øjesyn.

Som „lov“ ligger janteloven et eller andet sted mellem færdselsreglerne og tyngdekraften. Den er en kulturlov placeret på grænsen mellem de sociale vedtægter og naturlovene. I modsætning til naturens årsag-virkningsforhold, som ligger fast og kan verificeres ved kontrollerede eksperimenter, og til forskel fra den sociale vedtægt, som kan afskaffes med et pennestrøg, så er kulturlove en anderledes uhåndterlig gummibamse.

Janteloven er et udtryk for en side ved danskernes kollektive habitus. Den konverterer individuelle og sikkert universelle følelser som misundelse, skadefryd og smålighed og gør dem til udtryk for den danske nationalkarakter. Den hævder implicit, at disse følelser manifesterer sig med en særlig regelmæssighed og styrke i det danske samfund. Janteloven vidner om, at lighedstanken er gået over gevind; at det, der burde høre ind under de sociale institutioners område - velfærdstiltag, lovsikret lige adgang til uddannelser og sygehuse, folkepensionen - udarter til mere eller mindre bevidst kulturel smålighed og provinsialisme. Fællesskabet kanoniserer middelmådighed sådan, at det danske kollektiv ikke vil anerkende, at nogen er bedre end andre. „På det jævne, på det jævne...“

I løbet af mit feltarbejde på virksomheden Bang \& Olufsen dukkede janteloven op med spredte mellemrum. Da en direktør tog sin afsked, hed det således: „Det var janteloven, der drev ham på flugt.“ I flere tilfælde blev selve virksomheden $\mathrm{B} \& \mathrm{O}$ i aviserne fremstillet som en virksomhed, der netop havde trodset janteloven. 
Når janteloven bliver identificeret, er det som oftest $\varnothing$ konomiske entreprenører, der føler sig uretfærdigt behandlet på grund af det høje skattetryk, eller fordi de bliver forfulgt af bagmandspolitiet, eller det er kulturpersonligheder, som føler sig unfair behandlet i pressen.

Janteloven blev beskrevet i Aksel Sandemoses selvbiografiske roman En Flyktning krysser sitt spor om Esben Arnakke (sic!) og hans liv og opgør med sit undertrykkende ophav i Jante (Nykøbing Mors). Bogen handler om forholdene i en bestemt sammenhæng og social gruppe - om den måde, hvorpå en bestemt fattig lokalbefolkning for 100 år siden holdt sig selv nede. Grundmatricen i dette sociale helvede udtrykker Sandemose i en forkrøblet version af „De Ti Bud“, hvoraf det første og mest kendte er: „Du skal ikke tro, du er noget“.

Janteloven har altså i sin oprindelige tekst ikke noget at gøre med velhavende indfødte, som føler sig flået af skattevæsenet, professionelle cykelryttere med høje hæmatokritværdier eller filminstruktører, der føler sig dårligt behandlet i pressen. Sandemose beskriver undertrykkelsen inden for en gruppe med samme sociale position. Men lad os se bort fra det litterære forlæg. Sandemoses lov har for længst fået sit eget liv.

Når man beskæftiger sig med janteloven, ironien, hyggen - , dansk-heden - og søger at fremdrage og identificere alle disse havenisser og husdæmoner fra folkepsykologiens hængedynd, befinder man sig på gyngende grund. Data er uhåndgribelige og fortvivlende ad hoc. Empirien synes at udelukke langvarigt feltarbejde og deltagerobservation: Det ville kræve et uoverskueligt benarbejde at lave de kolossale komparative undersøgelser og indsamle de data, som vil kunne godtgøre, at ,janteloven“ virkelig svarer til en særlig dansk disposition, en kollektiv habitus. I én forstand er janteloven dog virkelig. Danskere taler og skriver om janteloven. Janteloven er et refleksivt fænomen. Vil man undersøge ,,janteloven“, virker „diskursanalysen“ i første omgang som en farbar vej.

Hvis man går på jagt efter janteloven, er dagbladene gode steder at lede. „Janteloven“ dukker op i avisernes debatklummer og læserbrevsspalter. Den bruges polemisk. Janteloven er det ultimative argument, „,trumfen, der slynges i bordet, når det sidste stik skal tages hjem“: „,Det er den sædvanlige jantelov”. Modstanderens holdning er dermed ikke rationelt motiveret, men udtryk for smålighed og national impuls

Når man i folkemunde taler om janteloven som en „lov“, så mener man, at der er en kulturel logik, som med næsten fysiologisk nødvendighed sætter sig igennem; at bestemte typer af adfærd udløser en usund - allergisk - kollektiv reaktion. På den anden side er loven ikke mere uafviselig, end at der er nogle andre danskere, der står udenfor og stiller diagnosen. Som regel er det sådan, at dem, der gør opmærksom på janteloven og objektiverer det folkelige kollektiv, ikke selv mener, at de eksekverer janteloven.

Janteloven er altså et indviklet kulturelt fænomen. Den er på en gang - emic, de indfødtes eget begreb om sig selv, og etic, den udenforstående betragters kategori.

De personer, massen eller folketribunalet, der angiveligt håndhæver jan- 
teloven, er jo ikke klar over, at de gør det og vil til enhver tid benægte det. I det idealtypiske jantelovs-setup gælder det også, at dem, som føler sig udsat for den, ikke selv påkalder sig den. Offeret har ingen stemme; der skal vidner til at kåre en martyr. Da Bille August for nogle år siden følte sig skidt behandlet af de danske anmeldere og på forsiden af BT erklærede, at han var „offer for janteloven“ - så klingede det patetisk og selvhøjtideligt og skabte mistanke om, at folketribunalet et eller andet sted måske alligevel havde en retfærdig sag.

Der skal altså tre til: et offer, et vidne og en forbryder (befolkningen) men i dette tilfælde består forbrydelsen eller det moralsk angribelige $\mathrm{i}$, at forbryderen (det sociale fællesskab) har handlet i overensstemmelse med loven. Jantespillet består altså af to moralske domme. Dels er der den dom, som folketribunalet angiveligt har fældet uretmæssigt over et offer, og dels er der en dommer - en appelinstans - som dømmer dommeren (befolkningen) og frikender det offer (Thorsen, August, Riis), som folkedomstolen havde sat i gabestokken.

Jakob Krause-Jensen, phd.-studerende Moesgaard, Aarhus Universitet 
